\title{
Molten Globule-Like Partially Folded State of Bacillus licheniformis $\alpha$-Amylase at Low pH Induced by 1,1,1,3,3,3-Hexafluoroisopropanol
}

\author{
Adyani Azizah Abd Halim, ${ }^{1}$ Mohammed Suleiman Zaroog, ${ }^{1,2}$ \\ Habsah Abdul Kadir, ${ }^{1}$ and Saad Tayyab ${ }^{1}$ \\ ${ }^{1}$ Biomolecular Research Group, Biochemistry Programme, Institute of Biological Sciences, Faculty of Science, \\ University of Malaya, 50603 Kuala Lumpur, Malaysia \\ ${ }^{2}$ Faculty of Applied Medical Sciences, University of Gezira, P.O. Box 20, 2667 Wad Medani, Sudan \\ Correspondence should be addressed to Saad Tayyab; saadtayyab2004@yahoo.com
}

Received 3 January 2014; Accepted 17 February 2014; Published 7 April 2014

Academic Editors: B. Sharma and A. Surguchov

Copyright ( 2014 Adyani Azizah Abd Halim et al. This is an open access article distributed under the Creative Commons Attribution License, which permits unrestricted use, distribution, and reproduction in any medium, provided the original work is properly cited.

\begin{abstract}
Effect of 1,1,1,3,3,3-hexafluoroisopropanol (HFIP) on acid-denatured Bacillus licheniformis $\alpha$-amylase (BLA) at pH 2.0 was investigated by far-UV CD, intrinsic fluorescence, and ANS fluorescence measurements. Addition of increasing HFIP concentrations led to an increase in the mean residue ellipticity at $222 \mathrm{~nm}\left(\mathrm{MRE}_{222 \mathrm{~nm}}\right)$ up to $1.5 \mathrm{M}$ HFIP concentration beyond which it sloped off. A small increase in the intrinsic fluorescence and a marked increase in the ANS fluorescence were also observed up to $0.4 \mathrm{M}$ HFIP concentration, both of which decreased thereafter. Far- and near-UV CD spectra of the HFIP-induced state observed at $0.4 \mathrm{M}$ HFIP showed significant retention of the secondary structures closer to native BLA but a disordered tertiary structure. Increase in the ANS fluorescence intensity was also observed with the HFIP-induced state, suggesting exposure of the hydrophobic clusters to the solvent. Furthermore, thermal denaturation of HFIP-induced state showed a non-cooperative transition. Taken together, all these results suggested that HFIP-induced state of BLA represented a molten globule-like state at $\mathrm{pH} 2.0$.
\end{abstract}

\section{Introduction}

Various noncovalent forces such as hydrogen bonding, electrostatic interactions, and hydrophobic interactions are known to stabilize the native protein structure $[1,2]$. The information about how and when different noncovalent forces assemble to guide protein folding can be obtained from the studies of the folding intermediates and denatured states obtained under non-native conditions such as high ionic strength, extremes of $\mathrm{pH}$, organic solvents, varied temperatures, or mild denaturing conditions $[3,4]$. At extreme $\mathrm{pH}$, various proteins are denatured due to the destabilizing repulsive forces between similar charges [5-7], whereas the attainment of the non-native states of proteins can be easily made with solvent perturbation [8-10].

Alcohols are widely used to induce secondary structure formation by stabilizing the $\alpha$-helical structure and reducing the exposure of peptide backbone in the unfolded proteins [11, 12]. A halogenol, 1,1,1,3,3,3-hexafluoroisopropanol (HFIP), a fluorine substituted alcohol is known to exhibit highest $\alpha$-helix inducing potential in many proteins [13-15]. Furthermore, low concentrations of both HFIP and 2,2,2trifluoroethanol (TFE) have been found to produce a molten globule-like state in acid-denatured proteins [16, 17]. The molten globule state is considered to provide the information about the early stages in the folding pathway where there are no specific interactions between the side chain residues of the protein $[18,19]$.

Bacillus licheniformis $\alpha$-amylase (BLA), a highly thermostable enzyme [20], has been widely used in various industries involving high temperature conditions such as in the production of maltodextrin and alcohols, baking, textile, and detergent industries for the initial starch hydrolysis [21-25]. Since BLA is known to possess higher thermal stability 
compared to Bacillus amyloliquefaciens $\alpha$-amylase (BAA) which has $81 \%$ identity and $88 \%$ similarity towards BLA, it is valuable to understand the folding mechanism and structural-stability of this enzyme [26]. Acid denaturation of BLA has been shown to complete at $\mathrm{pH} 2.0$ [27]. However, the molten globule state of BLA has been characterized at $\mathrm{pH} 4.0$ by various probes and it has been found more stable than pH 4.0 state of BAA upon guanidine hydrochloride denaturation and proteolytic digestion [27]. Moreover, a partially folded state has been found to accumulate at higher TFE concentrations in both native BLA and BAA but without the characteristics of a molten globule state [28]. Although many attempts have been made to elucidate the structure-stability relationship of BLA, effect of HFIP on the acid-denatured state of BLA at pH 2.0 has not been attempted so far. In this report, we present our data on HFIP-induced conformational transition in the acid-denatured BLA at $\mathrm{pH} 2.0$ using different probes such as far-UV and near-UV CD, intrinsic fluorescence, ANS fluorescence, and acrylamide quenching.

\section{Materials and Methods}

2.1. Materials. Bacillus licheniformis $\alpha$-amylase (BLA) (Cata$\log$ no. A4551), 8-anilino-1-naphthalene sulfonic acid (ANS) (Catalog no. A3125), acrylamide (Catalog no. A8887), Nacetyl-L-tryptophanamide (NATA) (Catalog no. A6501), and 1,1,1,3,3,3-hexafluoro-2-propanol (HFIP) (Catalog no. 105228) were purchased from Sigma-Aldrich Inc., St. Louis, MO, USA. Tris base was supplied by Amresco, Irvine, CA, USA. All other chemicals used were of analytical grade purity.

2.2. Analytical Procedures. BLA concentration was determined spectrophotometrically on a Shimadzu double-beam spectrophotometer, model UV-2450, using a molar extinction coefficient of $139,690 \mathrm{M}^{-1} \mathrm{~cm}^{-1}$ at $280 \mathrm{~nm}$ [29] whereas a molar extinction coefficient of $5000 \mathrm{M}^{-1} \mathrm{~cm}^{-1}$ at $350 \mathrm{~nm}$ was used to measure ANS concentration [30]. NATA concentration was determined using a molar extinction coefficient of $5630 \mathrm{M}^{-1} \mathrm{~cm}^{-1}$ at $280 \mathrm{~nm}$ [31].

2.3. Circular Dichroism. Circular dichroism (CD) measurements were performed at $25^{\circ} \mathrm{C}$ on a Jasco spectropolarimeter, model J-815, equipped with a thermostatically-controlled cell holder under constant nitrogen flow after calibrating the instrument with (+)-10-camphorsulfonic acid. The CD spectra were recorded in the far-UV $(200-250 \mathrm{~nm})$ and the near$\mathrm{UV}(250-300 \mathrm{~nm})$ regions using a protein concentration and cuvette path length of $1.7 \mu \mathrm{M} ; 1 \mathrm{~mm}$, and $3.4 \mu \mathrm{M} ; 10 \mathrm{~mm}$, respectively. A scan speed of $100 \mathrm{~nm} / \mathrm{min}$ and a response time of $1 \mathrm{~s}$ were employed throughout the spectral measurements. Each spectrum was the average of three scans and the spectra were corrected with suitable blanks after subtracting the CD spectral contribution of the blank solutions from the CD spectra of the protein samples. The results are expressed as mean residue ellipticity (MRE) in deg. $\mathrm{cm}^{2} \cdot \mathrm{dmol}^{-1}$, which was obtained using the following equation:

$$
\mathrm{MRE}=\frac{\theta \times \mathrm{MRW}}{10 \times c \times l},
$$

where different terms, such as $\theta, \mathrm{MRW}, c$, and $l$ refer to ellipticity in millidegrees, mean residue weight (molecular weight, $55200 \mathrm{Da}$ /number of amino acid residues, 483) of the protein, protein concentration in $\mathrm{mg} / \mathrm{mL}$, and the optical path length in $\mathrm{cm}$, respectively. Calculation of helical content was made using the method of Chen et al. [32].

2.4. Fluorescence Spectroscopy. Intrinsic fluorescence measurements were made in the wavelength range, 300-400 nm upon excitation at $280 \mathrm{~nm}$, on a Hitachi fluorescence spectrophotometer, model F-2500 using a protein concentration of $0.1 \mu \mathrm{M}$ in a $1 \mathrm{~cm}$ path length cuvette. Both excitation and emission slits were fixed at $10 \mathrm{~nm}$ each.

ANS fluorescence spectra of the sample containing ANS $(30 \mu \mathrm{M})$ and protein $(0.6 \mu \mathrm{M})$ in a ratio of $50: 1$ were recorded in the wavelength range, $400-600 \mathrm{~nm}$ upon excitation at $380 \mathrm{~nm}$. The fluorescence spectra were corrected for the fluorescence contribution of the blank solutions.

2.5. Preparation of Native and Acid-Denatured BLAs. Native BLA solution was prepared by dissolving the protein in $10 \mathrm{mM}$ Tris- $\mathrm{HCl}$ buffer, $\mathrm{pH}$ 7.0, whereas $10 \mathrm{mM}$ glycine- $\mathrm{HCl}$ buffer, $\mathrm{pH}$ 2.0, was used to prepare acid-denatured BLA. This solution was incubated at $4^{\circ} \mathrm{C}$ for 12 hours and filtered through $0.45 \mu \mathrm{m}$ millipore filter before use.

2.6. HFIP-Induced Structural Transitions. Titration of aciddenatured BLA with increasing HFIP concentrations was carried out by adding increasing concentrations $(0-6.0 \mathrm{M})$ of HFIP to a constant volume $(0.5 \mathrm{~mL})$ of the protein solution taken in different tubes. The total volume of the mixture was made to $5.0 \mathrm{~mL}$ with $10 \mathrm{mM}$ glycine- $\mathrm{HCl}$ buffer, $\mathrm{pH} 2.0$. Blank solutions were prepared in the same way except that the protein solution was substituted with the same volume of the above buffer. The $\mathrm{pH}$ of the incubation mixture was found to remain within $\pm 0.1 \mathrm{pH}$ unit. The $\mathrm{CD}$ and fluorescence spectral measurements were made after $30 \mathrm{~min}$ incubation at $25^{\circ} \mathrm{C}$, as suggested earlier [14].

For ANS-binding experiments, $0.5 \mathrm{~mL}$ of ANS stock solution $(300 \mu \mathrm{M})$ was added to the incubation mixture containing fixed concentration of the protein $(0.6 \mu \mathrm{M})$ and varying HFIP concentrations $(0-6.0 \mathrm{M})$, which were preincubated at $25^{\circ} \mathrm{C}$ for $30 \mathrm{~min}$. The sample incubation mixture $(5.0 \mathrm{~mL})$ was incubated for additional $20 \mathrm{~min}$ before spectral measurements. Blank solutions without protein were prepared in the same way except for substituting protein with the buffer and their fluorescence contribution (if any) was subtracted from the fluorescence spectra of the protein.

2.7. Acrylamide Quenching. Acrylamide quenching experiments were performed on a Hitachi fluorescence spectrophotometer, model F-2500, using a concentration of $0.1 \mu \mathrm{M}$ and $1.7 \mu \mathrm{M}$ for BLA and NATA, respectively. Increasing volumes 
TABLE 1: Physical characteristics of different conformational states of BLA.

\begin{tabular}{lccc}
\hline Variable & Native state & Acid-denatured state & HFIP-induced state \\
\hline $\mathrm{MRE}_{222 \mathrm{~nm}}\left(\mathrm{deg} \cdot \mathrm{cm}^{2} \cdot \mathrm{dmol}^{-1}\right)$ & -7557 & -4649 & -8615 \\
$\%$ Helix $^{\mathrm{a}}$ & $\sim 17$ & $\sim 8$ & $\sim 21$ \\
Fluorescence intensity & 871.2 & 241.8 & 259.8 \\
Emission maximum $\left(\lambda_{\text {ex }}=280 \mathrm{~nm}\right)$ & $337 \mathrm{~nm}$ & $344 \mathrm{~nm}$ & $341 \mathrm{~nm}$ \\
ANS fluorescence intensity & 33 & 200 & 481 \\
Emission maximum $\left(\lambda_{\text {ex }}=380 \mathrm{~nm}\right)$ & $448 \mathrm{~nm}$ & $474 \mathrm{~nm}$ & $477 \mathrm{~nm}$ \\
Cooperativity (thermal transition) & Yes & No & No \\
\hline
\end{tabular}

${ }^{a}$ Calculated by the method of Chen et al. [32].

of acrylamide stock solution $(2.0 \mathrm{M})$ were added to $0.5 \mathrm{~mL}$ protein solution $(0.6 \mu \mathrm{M})$ of different BLA samples (native and acid-denatured BLAs both in the absence and the presence of 0.4 M HFIP) or NATA solution to get the desired acrylamide concentration in the range, $0.02-0.25 \mathrm{M}$. The total volume $(3.0 \mathrm{~mL})$ was made with the respective buffers and the final incubation mixture was kept in dark for 30 min before fluorescence measurements. Emission spectra were recorded in the wavelength range, $300-400 \mathrm{~nm}$, upon excitation at $295 \mathrm{~nm}$ in order to excite the tryptophan (Trp) residues only, using slit widths of $10 \mathrm{~nm}$. The fluorescence intensity values of each sample were corrected with respective blanks and the data were analyzed following the Stern-Volmer equation as described earlier [33].

2.8. Thermal Denaturation. Effect of temperature $\left(25-100^{\circ} \mathrm{C}\right)$ on different states of BLA (native, acid-denatured, and HFIPinduced states) was studied using $\mathrm{CD}$ spectral change at $222 \mathrm{~nm}$ with a scan rate of $1.0^{\circ} \mathrm{C} / \mathrm{min}$. Transformation of ellipticity values into MRE values was made in the same way as described above.

\section{Results and Discussion}

3.1. HFIP-Induced Structural Transitions in the Acid-Denatured BLA. Figure 1 shows the effect of increasing HFIP concentrations on the acid-denatured BLA at pH 2.0 as monitored by $\mathrm{MRE}_{222 \mathrm{~nm}}$ (a), intrinsic fluorescence (b), and ANS fluorescence (c) measurements. As can be seen from Figure 1(a), a marked increase in the $-\mathrm{MRE}_{222 \mathrm{~nm}}$ value of the acid-denatured BLA was observed on increasing the HFIP concentration up to $1.5 \mathrm{M}$, beyond which it sloped off. Similarly, increase in both intrinsic fluorescence and ANS fluorescence intensities was observed up to 0.4 M HFIP, being more significant with ANS fluorescence (2.4-fold) compared to intrinsic fluorescence. Further increase in the HFIP concentration led to a gradual decrease in both fluorescence intensities, tailing off around 1.2 M HFIP. Increase in the intrinsic fluorescence intensity at early HFIP concentration (up to 0.4 M HFIP) may be attributed to the change in the microenvironment around tyrosine (Tyr) and tryptophan (Trp) residues due to the separation of negatively charged residues (quenchers) such as glutamate or aspartate from the vicinity of the aromatic residues [34]. This seems possible in view of the increase in the secondary structures of the acid-denatured BLA as shown in Figure 1(a). On the other hand, presence of trifluoromethyl groups in the fluorinated alcohols may account for the observed decrease in the fluorescence intensity at higher HFIP concentrations. Both high electronegativity of fluorine $(\mathrm{F})$ atoms and large field effects of trifluoromethyl groups can make these fluoroalcohols as active proton donors $[35,36]$, which may result in the quenching of Trp fluorescence due to excited state proton transfer from fluorinated alcohols to indole ring of Trp residues [35].

Marked increase in the ANS fluorescence intensity, as observed up to 0.4 M HFIP, reflected the formation of a compact denatured state with a large number of surface-exposed hydrophobic clusters [5], which were otherwise absent in the acid-denatured state. This was in accordance with our intrinsic fluorescence results, where HFIP-induced state showed some burial of aromatic chromophores. Decrease in the ANS fluorescence intensity beyond $0.4 \mathrm{M}$ HFIP reflected the disruption of the hydrophobic clusters. In view of the increased $\mathrm{MRE}_{222 \mathrm{~nm}}$ value and increased ANS binding observed at 0.4 M HFIP, it appears that the acid-denatured BLA might be able to form a molten globule-like state in the presence of $0.4 \mathrm{M}$ HFIP.

3.2. Characterization of the HFIP-Induced State. The HFIPinduced state obtained at $0.4 \mathrm{M}$ HFIP was characterized using far- and near-UV CD, intrinsic fluorescence and ANS fluorescence spectra, acrylamide quenching, and thermal denaturation studies.

3.2.1. Far-UV CD Spectra. A comparison of secondary structural characteristics of different states of BLA was made using far-UV CD spectroscopy. Figure 2(a) shows far-UV CD spectra of the native, the acid-denatured, and the HFIPinduced states of BLA. As evident from the figure, native state of BLA was characterized by the presence of two minima around 208 and $222 \mathrm{~nm}$, characteristic of $\alpha$-helical structure $[28,37]$, which were shifted towards lower wavelength side at 205 and $220 \mathrm{~nm}$ along with reduced MRE values in the aciddenatured state (Figure 2(a)). A significant reduction ( 38\%) in the $\mathrm{MRE}_{222 \mathrm{~nm}}$ value in the acid-denatured state indicated significant loss of the secondary structures (Table 1). Interestingly, far-UV CD spectrum of the HFIP-induced state was found closer to the far-UV CD spectrum of the native protein, showing $\sim 85 \%$ increase in the $\mathrm{MRE}_{222 \mathrm{~nm}}$ value from that obtained with the acid-denatured state, being -8615 


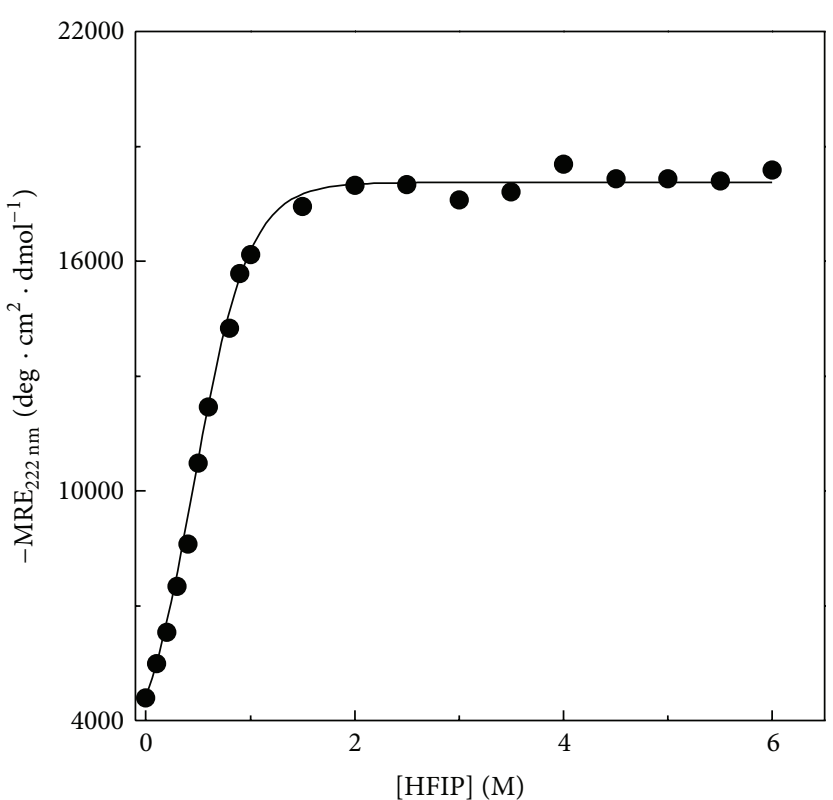

(a)

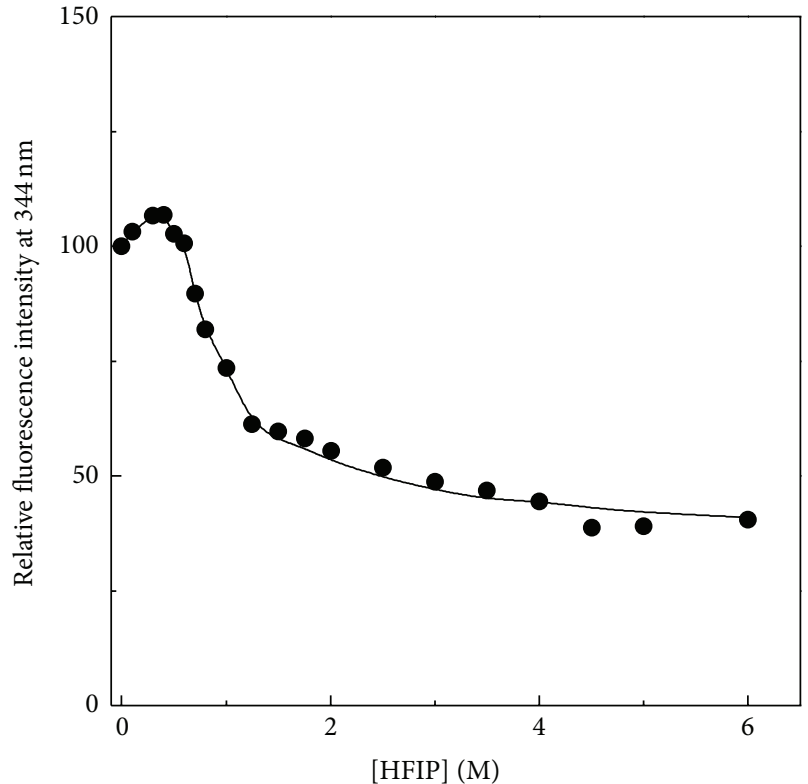

(b)

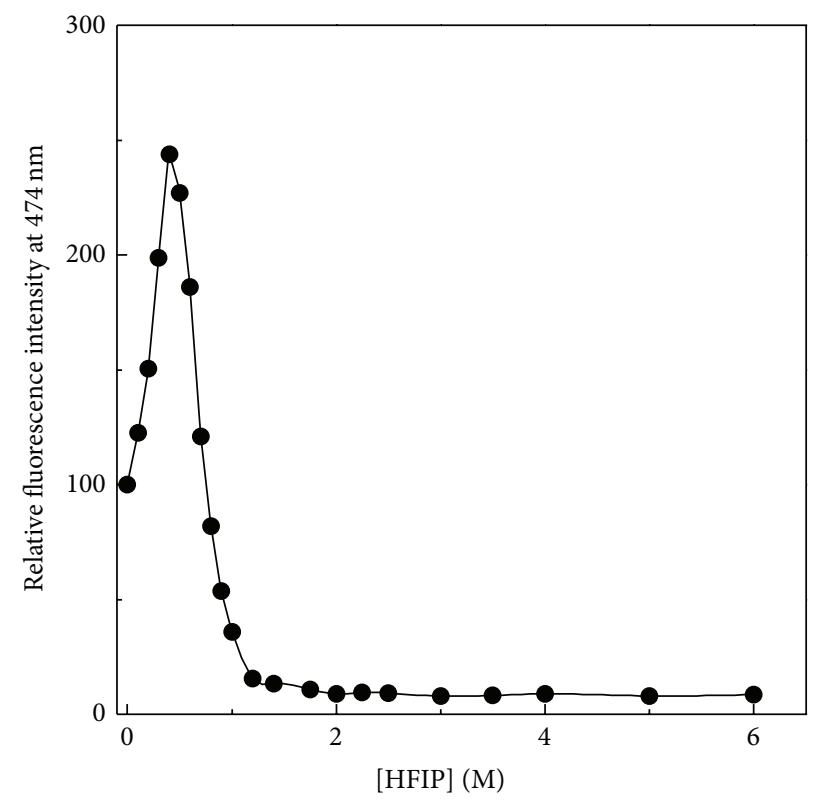

(c)

FIGURE 1: Effect of increasing HFIP concentrations on the spectral characteristics of the acid-denatured BLA at pH 2.0 and $25^{\circ} \mathrm{C}$, as monitored by (a) $\mathrm{MRE}_{222 \mathrm{~nm}}$ measurements, (b) intrinsic fluorescence measurements at $344 \mathrm{~nm}$ upon excitation at $280 \mathrm{~nm}$, and (c) ANS fluorescence measurements at $474 \mathrm{~nm}$ upon excitation at $380 \mathrm{~nm}$.

compared to -7557, obtained with the native BLA (Table 1). A quantitative analysis of these spectra was made by calculating the percentage $\alpha$-helical content for these states. The value of the $\alpha$-helical content decreased from $\sim 17 \%$ (for native BLA) to $\sim 8 \%$ in the acid-denatured state, showing significant loss of the secondary structure but regained further in the HFIPinduced state, showing $\sim 21 \% \alpha$-helical content (Table 1). This result was in accordance with earlier observations, as alcohols are known to increase $\alpha$-helical structure by promoting local polar interactions such as hydrogen bonds in proteins $[12,38]$.
Such effect has been found more with fluoroalcohols compared to alkyl alcohols $[14,15]$.

3.2.2. Near-UV CD Spectra. Near-UV CD spectrum provides information about the protein's tertiary structure. Figure 2(b) shows near-UV CD spectra of different states of BLA. Several positive signals (maxima) and two minima around 283 and $290 \mathrm{~nm}$ characterized the near-UV CD spectrum of native BLA, suggesting fixed orientation of various aromatic 


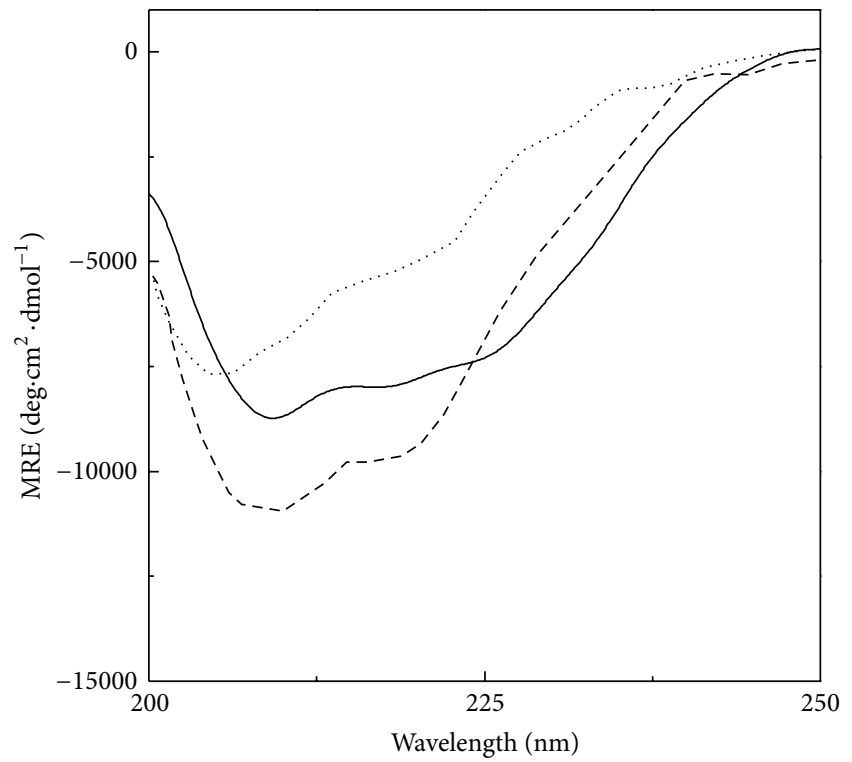

(a)

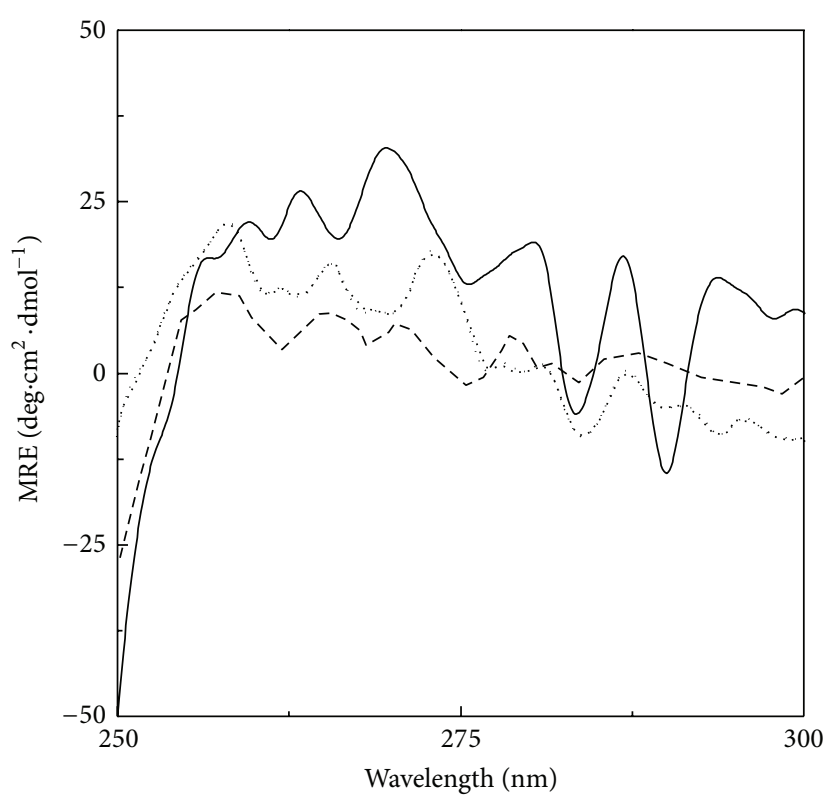

(b)

FIGURE 2: Far-UV (a) and near-UV (b) CD spectra of different conformational states of BLA, as obtained at $25^{\circ} \mathrm{C}$ using a protein concentration and cuvette path length of $1.7 \mu \mathrm{M} ; 1 \mathrm{~mm}$ and $3.4 \mu \mathrm{M} ; 10 \mathrm{~mm}$ for far-UV and near-UV CD spectral measurements, respectively. Native state $(-)$, acid-denatured state $(\cdots)$, and HFIP-induced state (- - ).

residues under native conditions. These near-UV CD spectral characteristics of BLA were similar to those reported earlier [28]. Significant alteration in the near-UV CD spectrum of the acid-denatured BLA, particularly in the wavelength range, $260-300 \mathrm{~nm}$ suggested more flexible orientation of the majority of the aromatic residues. As can be seen from the figure, some regions of BLA were significantly affected, while others showed least alteration in the acid-denatured state, suggesting partial denaturation. This was in accordance with previous reports on the acid-denatured proteins, showing the presence of significant residual structure $[39,40]$. Presence of $0.4 \mathrm{M}$ HFIP did not produce any significant alteration in the tertiary structure of the acid-denatured BLA. These results indicated that the HFIP-induced state retained similar secondary structures as that found in native BLA but a disordered tertiary structure, suggesting the characteristics of the molten globule-like state $[41,42]$.

3.2.3. Intrinsic Fluorescence Spectra. The information about the tertiary structural alteration in a protein can also be obtained from its intrinsic fluorescence spectra. The intrinsic fluorescence spectrum of native BLA (Figure 3(a)) was characterized by the presence of an emission maximum around $337 \mathrm{~nm}$ due to the abundance of Trp residues [43]. BLA has a total of 17 Trp and 31 Tyr residues [44]. A marked decrease $(\sim 72 \%)$ in the fluorescence intensity accompanied by a significant red shift $(7 \mathrm{~nm})$ from $337 \mathrm{~nm}$ to $344 \mathrm{~nm}$ was observed in the intrinsic fluorescence spectrum of the acid-denatured BLA (Figure 3(a), Table 1). These results indicated the change in the microenvironment around Tyr and Trp residues from nonpolar to polar, as a result of partial unfolding of the protein in the acid-denatured state [45]. A small increase $(\sim 7 \%)$ in the fluorescence intensity accompanied by a blue shift of $3 \mathrm{~nm}$ characterized the fluorescence spectrum of the HFIP-induced state. Such small changes in the fluorescence characteristics of the HFIP-induced state indicated slight internalization of Trp and Tyr residues to a more hydrophobic environment due to local structural perturbation [17, 34]. These results were similar to the near-UV CD spectral results, showing little alteration in the tertiary structure of the HFIPinduced state. In other words, the tertiary structure of HFIPinduced state remained disorganized.

3.2.4. ANS Fluorescence Spectra. ANS binding is used to probe the exposure of the hydrophobic clusters in proteins [46]. Upon binding to the hydrophobic regions in the protein, ANS produces a fluorescence spectrum in the wavelength range, $400-600 \mathrm{~nm}$ upon excitation at $380 \mathrm{~nm}$. ANS has shown greater affinity towards the acid-denatured state than the native state of proteins, suggesting exposure of the buried hydrophobic patches to the solvent in the acid-denatured state $[27,47,48]$. The ANS fluorescence spectra of different states of BLA are shown in Figure 3(b). ANS binding to native BLA produced a weak fluorescence signal with an emission maximum at $448 \mathrm{~nm}$, suggesting burial of the hydrophobic ANS binding clusters in the protein interior. A marked increase $(\sim 6$-fold) in the ANS fluorescence intensity along with a significant red shift $(26 \mathrm{~nm})$ in the emission maximum, observed with the acid-denatured BLA, indicated exposure of the solvent accessible hydrophobic regions and agreed well with the previous reports on other proteins $[49,50]$. Interestingly, ANS fluorescence spectrum of the HFIP-induced state showed 2.4-fold increase in the ANS fluorescence intensity accompanied by a $3 \mathrm{~nm}$ red shift from that obtained with 


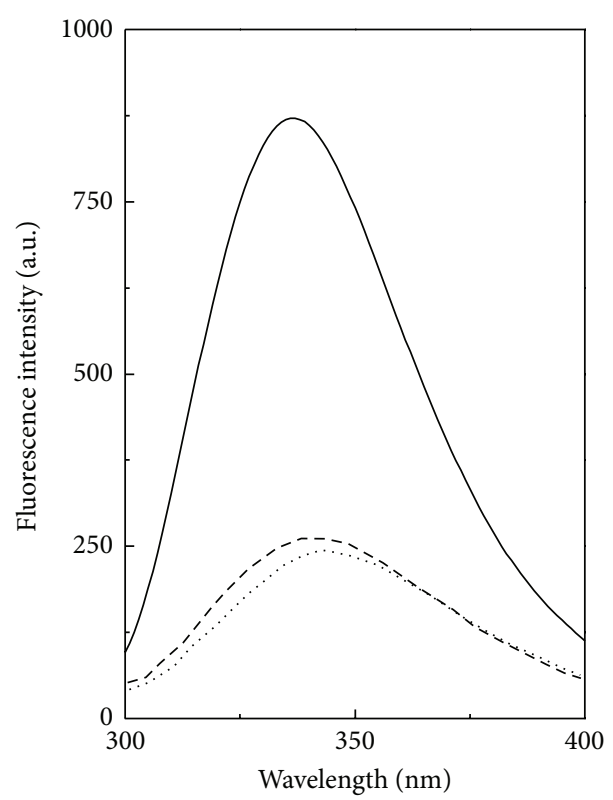

(a)

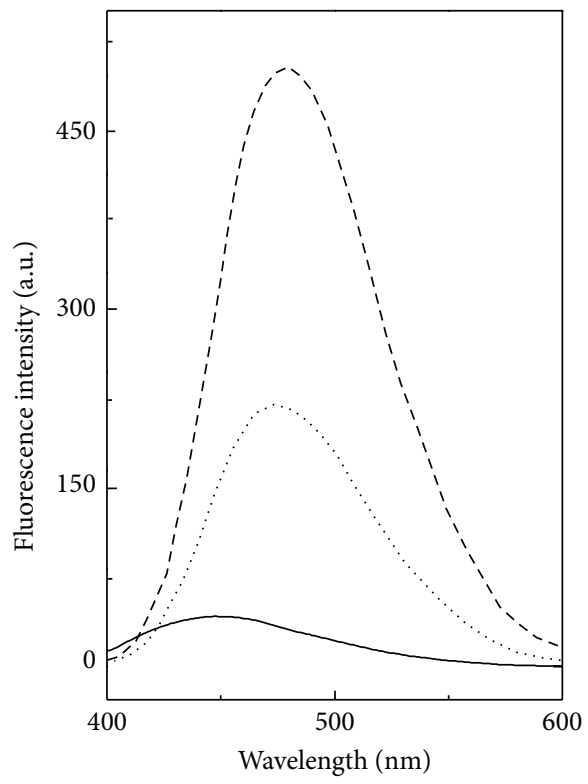

(b)

FIGURE 3: Intrinsic fluorescence (a) and ANS fluorescence (b) spectra of different conformational states of BLA, as obtained at $25^{\circ} \mathrm{C}$ using a protein concentration of $0.1 \mu \mathrm{M}$ and $0.6 \mu \mathrm{M}$ for intrinsic fluorescence and ANS fluorescence measurements, respectively. Native state (-), acid-denatured state $(\cdots)$, and HFIP-induced state (- - ).

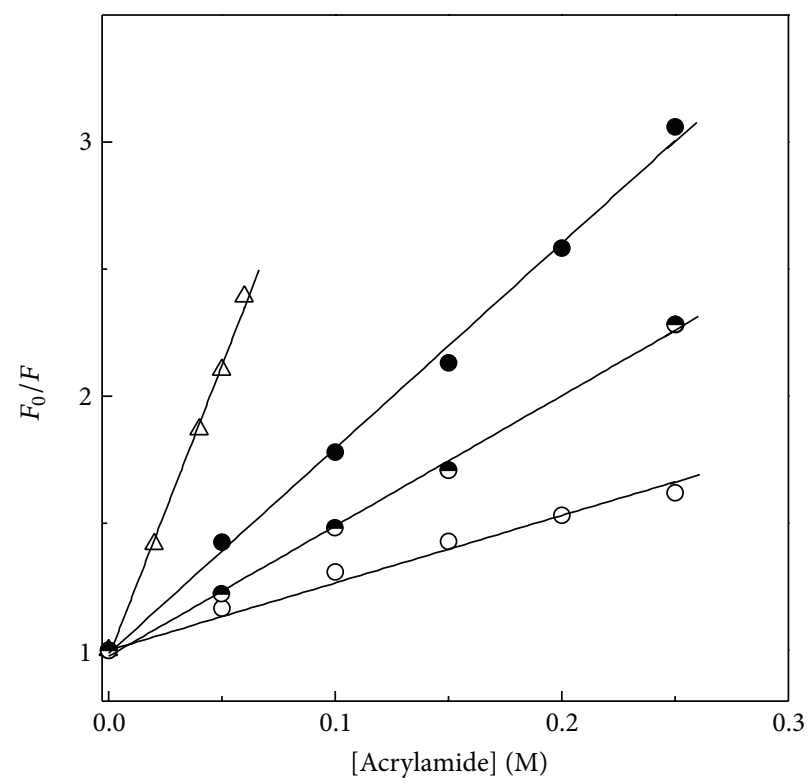

FIGURE 4: Stern-Volmer plots of different conformational states of BLA, as studied by acrylamide quenching using a protein concentration of $0.1 \mu \mathrm{M}$. Native state $(\bigcirc)$, acid-denatured state $(\bullet)$, and HFIP-induced state $(\bullet)$. Acrylamide quenching data obtained with NATA is shown by symbols $(\triangle)$.

the acid-denatured state, suggesting more exposure of the ANS binding sites (more hydrophobic clusters) to the solvent (Figure 3(b), Table 1) [48].

3.2.5. Acrylamide Quenching. Acrylamide quenching studies were also made to evaluate the exposure of Trp residues in different states of BLA. The results were fitted into the
Stern-Volmer plots (Figure 4) and values of the Stern-Volmer constant, $K_{\mathrm{SV}}$, obtained from the slope of the linear plots, are given in Table 2. For the complete exposure of Trp residues, data of NATA was used as a reference. The $K_{\mathrm{SV}}$ value of NATA $\left(22.8 \mathrm{M}^{-1}\right)$ was found to be significantly higher than the value obtained for different states of BLA. This value was similar to the $K_{\mathrm{SV}}$ value reported for NATA in several earlier reports [51, 52]. $K_{\mathrm{SV}}$ value $\left(8.1 \mathrm{M}^{-1}\right)$ of the acid-denatured BLA was found 
TABLE 2: Values of Stern-Volmer constant $\left(K_{\mathrm{SV}}\right)$ of different conformational states of BLA, as obtained from acrylamide quenching data.

\begin{tabular}{lc}
\hline BLA & $K_{\mathrm{SV}}\left(\mathrm{M}^{-1}\right)$ \\
\hline Native state & 2.5 \\
Acid-denatured state & 8.1 \\
HFIP-induced state & 5.1 \\
NATA & 22.8 \\
\hline
\end{tabular}

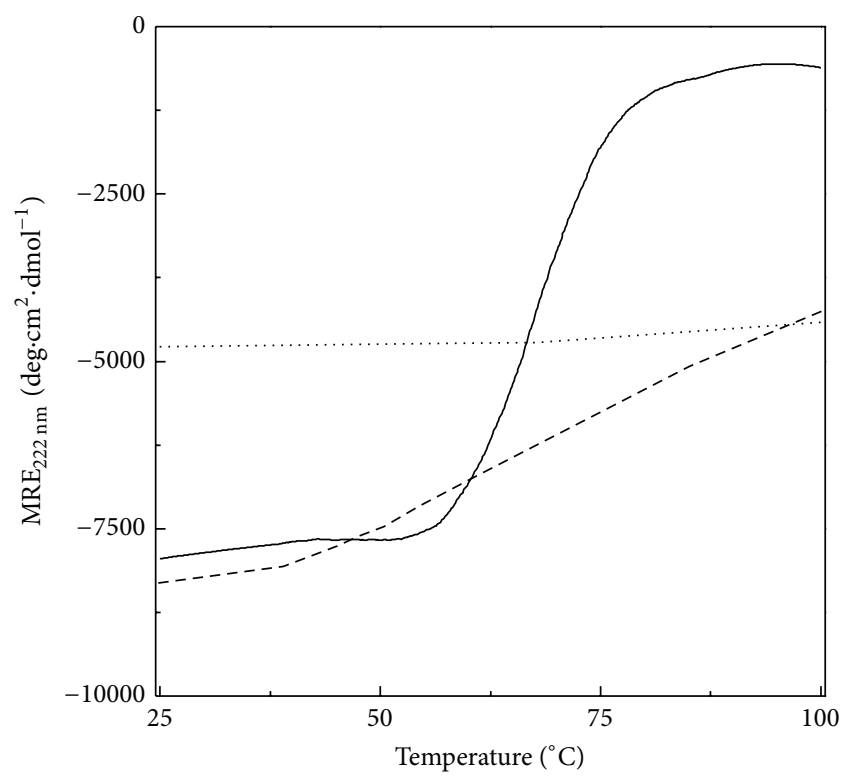

FIgURE 5: Temperature dependence of the far-UV CD spectral signal, $\mathrm{MRE}_{222 \mathrm{~nm}}$ of different conformational states of BLA. Native state $(-)$, acid-denatured state $(\cdots)$, and HFIP-induced state $(---)$.

higher than the native BLA $\left(2.5 \mathrm{M}^{-1}\right)$ but much lower than the $K_{\mathrm{SV}}$ value obtained for NATA, suggesting more exposure of Trp residues in the acid-denatured state compared to native BLA. However, a significantly lower value of $K_{\mathrm{SV}}$ compared to NATA suggested that acid denaturation did not unfold the protein completely [53]. A marked quenching of the intrinsic fluorescence compared to the native protein has also been reported for BAA at pH 2.25 [54]. Decrease in the $K_{\mathrm{SV}}$ value from $8.1 \mathrm{M}^{-1}$ (for the acid-denatured BLA) to $5.1 \mathrm{M}^{-1}$ (for the HFIP-induced state) clearly suggested burial of Trp residues due to local structural changes [43]. In other words, HFIPinduced state showed internalization of Trp residues to the non-polar environment compared to the acid-denatured BLA and agreed well with a previous report on stem bromelain, where presence of HFIP has been shown to decrease the $K_{\mathrm{SV}}$ value compared to the acid-denatured protein [17].

3.2.6. Thermal Denaturation. Figure 5 shows thermal denaturation curves of different states of BLA, as obtained from $\mathrm{MRE}_{222 \mathrm{~nm}}$ measurements. Thermal denaturation of native BLA showed a cooperative transition, characterized by a sharp decrease in $-\mathrm{MRE}_{222 \mathrm{~nm}}$ within the temperature range, $60-77^{\circ} \mathrm{C}$ with the occurrence of the melting temperature
$\left(T_{m}\right)$ value at $68^{\circ} \mathrm{C}$. This agreed well with the reported $\mathrm{T}_{m}$ value of BLA, obtained from DSC experiments [55]. The cooperative thermal transition of the native BLA has also been shown in an earlier study [56]. On the other hand, the acid-denatured BLA did not produce any significant change in the $\mathrm{MRE}_{222 \mathrm{~nm}}$ value throughout the temperature range, indicating thermal stability of the enzyme in the acid-denatured state with respect to the $\alpha$-helical content. It appears that the acid-denatured state might be similar to the thermal-denatured state in terms of stability. In a previous report, Zaroog and Tayyab [57] have also shown thermal stability of the acid-denatured glucoamylase within the temperature range, $25-100^{\circ} \mathrm{C}$. Interestingly, acid-denatured BLA in the presence of $0.4 \mathrm{M}$ HFIP (HFIP-induced state), though retained similar secondary structure as that found in native BLA state (Figure 2(a)) but showed a non-cooperative thermal transition (Figure 5, Table 1), a characteristic feature of the molten globule state $[58,59]$. Formation of a compact-denatured conformation of cytochrome $\mathrm{c}$ at $\mathrm{pH} 1.9$ has also been shown to be accumulated in the presence of HFIP [16].

\section{Conclusion}

In summary, HFIP-induced state of BLA was found to possess the characteristics of a molten globule state, showing a nativelike secondary structure as evident from the far-UV CD spectra, a disrupted tertiary structure as reflected from the nearUV CD spectra and intrinsic fluorescence spectra, increased ANS binding, and non-cooperative thermal transition.

\section{Conflict of Interests}

The authors declare that there is no conflict of interests regarding the publication of this paper.

\section{Acknowledgments}

This research was supported by High Impact Research MoE Grant (UMC/625/1/HIR/MoE/SC/02) from the Ministry of Education, Malaysia, University of Malaya Research Grant (RG160-11AFR) and Postgraduate Research Fund (PV018/ 2011B). Saad Tayyab is a member of the CRYSTAL research group. Adyani Azizah Abd Halim also acknowledges UM scholarship. The authors thank the Dean of Faculty of Science and the Head of Institute of Biological Sciences for providing all necessary facilities and working atmosphere to carry out this work.

\section{References}

[1] K. Flanagan, J. Walshaw, S. L. Price, and J. M. Goodfellow, "Solvent interactions with $\pi$ ring systems in proteins," Protein Engineering, vol. 8, no. 2, pp. 109-116, 1995.

[2] V. Munoz, P. Cronet, E. Lopez-Hernandez, and L. Serrano, "Analysis of the effect of local interactions on protein stability," Folding and Design, vol. 1, no. 3, pp. 167-178, 1996.

[3] N. Singh, R. Kumar, M. V. Jagannadham, and A. M. Kayastha, "Evidence for a molten globule state in Cicer $\alpha$-galactosidase 
induced by $\mathrm{pH}$, temperature and guanidine hydrochloride," Applied Biochemistry and Biotechnology, vol. 169, no. 8, pp. 23152325, 2013.

[4] D. Kishore, S. Kundu, and A. M. Kayastha, "Thermal, chemical and $\mathrm{pH}$ induced denaturation of a multimeric $\beta$-galactosidase reveals multiple unfolding pathways," PLoS ONE, vol. 7, no. 11, Article ID e50380, 2012.

[5] Y. Goto and A. L. Fink, "Conformational states in $\beta$-lactamase: molten-globule states at acidic and alkaline $\mathrm{pH}$ with high salt," Biochemistry, vol. 28, no. 3, pp. 945-952, 1989.

[6] D. B. Volkin and A. M. Klibanov, "Minimizing protein inactivation," in Protein Function: A Practical Approach, T. E. Creighton, Ed., pp. 1-24, Information Press, Oxford, UK, 1989.

[7] T. Konno, "Conformational diversity of acid-denatured cytochrome c studied by a matrix analysis of far-UV CD spectra," Protein Science, vol. 7, no. 4, pp. 975-982, 1998.

[8] C. Tanford, "Protein Denaturation," Advances in Protein Chemistry, vol. 23, pp. 121-282, 1968.

[9] S. N. Timasheff, "The control of protein stability and association by weak interactions with water: how do solvents affect these processes?" Annual Review of Biophysics and Biomolecular Structure, vol. 22, pp. 67-97, 1993.

[10] V. N. Uversky, N. V. Narizhneva, S. O. Kirschstein, S. Winter, and G. Löber, "Conformational transitions provoked by organic solvents in $\beta$-lactoglobulin: can a molten globule like intermediate be induced by the decrease in dielectric constant?" Folding and Design, vol. 2, no. 3, pp. 163-172, 1997.

[11] P. D. Thomas and K. A. Dill, "Local and nonlocal interactions in globular proteins and mechanisms of alcohol denaturation," Protein Science, vol. 2, no. 12, pp. 2050-2065, 1993.

[12] Y. Liu and D. W. Bolen, "The peptide backbone plays a dominant role in protein stabilization by naturally occurring osmolytes," Biochemistry, vol. 34, no. 39, pp. 12884-12891, 1995.

[13] N. Hirota, K. Mizuno, and Y. Goto, "Group additive contributions to the alcohol-induced $\alpha$-helix formation of melittin: implication for the mechanism of the alcohol effects on proteins," Journal of Molecular Biology, vol. 275, no. 2, pp. 365-378, 1998.

[14] Y. Kumar, S. Tayyab, and S. Muzammil, "Molten-globule like partially folded states of human serum albumin induced by fluoro and alkyl alcohols at low pH," Archives of Biochemistry and Biophysics, vol. 426, no. 1, pp. 3-10, 2004.

[15] M. S. Zaroog and S. Tayyab, "Halogenol- versus alkanolinduced structural transitions of acid-denatured glucoamylase: characterization of alcohol-induced states," Process Biochemistry, vol. 48, no. 5-6, pp. 853-862, 2013.

[16] T. Konno, J. Iwashita, and K. Nagayama, "Fluorinated alcohol, the third group of cosolvents that stabilize the molten-globule state relative to a highly denatured state of cytochrome c," Protein Science, vol. 9, no. 3, pp. 564-569, 2000.

[17] S. Dave, H. K. Dkhar, M. P. Singh et al., "Hexafluoroisopropanol-induced helix-sheet transition of stem bromelain: correlation to function," International Journal of Biochemistry and Cell Biology, vol. 42, no. 6, pp. 938-947, 2010.

[18] C. R. Matthews, "Pathways of protein folding," Annual Review of Biochemistry, vol. 62, pp. 653-683, 1993.

[19] S. Samaddar, A. K. Mandal, S. K. Mondal, K. Sahu, K. Bhattacharyya, and S. Roy, "Solvation dynamics of a protein in the pre molten globule state," Journal of Physical Chemistry B, vol. 110, no. 42, pp. 21210-21215, 2006.
[20] A. Pandey, P. Nigam, C. R. Soccol, V. T. Soccol, D. Singh, and R. Mohan, "Advances in microbial amylases," Biotechnology and Applied Biochemistry, vol. 31, no. 2, pp. 135-152, 2000.

[21] Y. B. Ammar, T. Matsubara, K. Ito et al., "New action pattern of a maltose-forming $\alpha$-amylase from Streptomyces sp. and its possible application in bakery," Journal of Biochemistry and Molecular Biology, vol. 35, no. 6, pp. 568-575, 2002.

[22] S. Varavinit, N. Chaokasem, and S. Shobsngob, "Immobilization of a thermostable alpha-amylase," Science Asia, vol. 28, pp. 247251, 2002.

[23] C. Bessler, J. Schmitt, K.-H. Maurer, and R. D. Schmid, "Directed evolution of a bacterial $\alpha$-amylase: toward enhanced pH-performance and higher specific activity," Protein Science, vol. 12, no. 10, pp. 2141-2149, 2003.

[24] N. Declerck, M. Machius, P. Joyet, G. Wiegand, R. Huber, and C. Gaillardin, "Hyperthermostabilization of Bacillus licheniformis $\alpha$-amylase and modulation of its stability over a $50^{\circ} \mathrm{C}$ temperature range," Protein Engineering, vol. 16, no. 4, pp. 287-293, 2003.

[25] D. R. Nagarajan, G. Rajagopalan, and C. Krishnan, "Purification and characterization of a maltooligosaccharide-forming $\alpha$ amylase from a new Bacillus subtilis KCC103," Applied Microbiology and Biotechnology, vol. 73, no. 3, pp. 591-597, 2006.

[26] N. Declerck, M. Machius, P. Joyet, G. Wiegand, R. Huber, and C. Gaillardin, "Engineering the thermostability of Bacillus licheniformis $\alpha$-amylase," Biologia, vol. 57, no. 11, pp. 203-211, 2002.

[27] M. M. Shokri, K. Khajeh, J. Alikhajeh et al., "Comparison of the molten globule states of thermophilic and mesophilic $\alpha$-amylases," Biophysical Chemistry, vol. 122, no. 1, pp. 58-65, 2006.

[28] S. M. Asghari, K. Khajeh, B. Ranjbar, R. H. Sajedi, and H. Naderi-Manesh, "Comparative studies on trifluoroethanol (TFE) state of a thermophilic $\alpha$-amylase and its mesophilic counterpart: limited proteolysis, conformational analysis, aggregation and reactivation of the enzymes," International Journal of Biological Macromolecules, vol. 34, no. 3, pp. 173-179, 2004.

[29] A. R. Nazmi, T. Reinisch, and H.-J. Hinz, "Calorimetric studies on renaturation by $\mathrm{CaCl}_{2}$ addition of metal-free $\alpha$-amylase from Bacillus licheniformis (BLA)," Journal of Thermal Analysis and Calorimetry, vol. 91, no. 1, pp. 141-149, 2008.

[30] P. M. Mulqueen and M. J. Kronman, "Binding of naphthalene dyes to the $\mathrm{N}$ and A conformers of bovine $\alpha$-lactalbumin," Archives of Biochemistry and Biophysics, vol. 215, no. 1, pp. 28-39, 1982.

[31] R. W. Alston, M. Lasagna, G. R. Grimsley, J. M. Scholtz, G. D. Reinhart, and C. N. Pace, "Peptide sequence and conformation strongly influence tryptophan fluorescence," Biophysical Journal, vol. 94, no. 6, pp. 2280-2287, 2008.

[32] Y. H. Chen, J. T. Yang, and H. M. Martinez, "Determination of the secondary structures of proteins by circular dichroism and optical rotator dispersion," Biochemistry, vol. 11, no. 22, pp. 4120-4131, 1972.

[33] M. R. Eftink and C. A. Ghiron, "Fluorescence quenching studies with proteins," Analytical Biochemistry, vol. 114, no. 2, pp. 199227, 1981.

[34] F. Naseem and R. H. Khan, "Structural intermediates of acid unfolded Con-A in different co-solvents: fluoroalcohols and polyethylene glycols," International Journal of Biological Macromolecules, vol. 42, no. 2, pp. 158-165, 2008.

[35] J. D. Roberts, R. L. Webb, and E. A. McElhill, "The electrical effect of the trifluoromethyl group," Journal of the American Chemical Society, vol. 72, no. 1, pp. 408-411, 1950. 
[36] C. M. Othon, O.-H. Kwon, M. M. Lin, and A. H. Zewail, "Solvation in protein (un)folding of melittin tetramer-monomer transition," Proceedings of the National Academy of Sciences of the United States of America, vol. 106, no. 31, pp. 12593-12598, 2009.

[37] B. F. Shaw, G. F. Schneider, B. Bilgiçer et al., "Lysine acetylation can generate highly charged enzymes with increased resistance toward irreversible inactivation," Protein Science, vol. 17, no. 8, pp. 1446-1455, 2008.

[38] O. B. Ptitsyn, “The molten globule state," in Protein Folding, T. E. Creighton, Ed., pp. 243-300, W.H. Freeman and Company, New York, NY, USA, 1992.

[39] V. Clément-Collin, A. Leroy, C. Monteilhet, and L. P. Aggerbeck, "Mimicking lipid-binding-induced conformational changes in the human apolipoprotein $\mathrm{E} \mathrm{N}$-terminal receptor binding domain: effects of low $\mathrm{pH}$ and propanol," European Journal of Biochemistry, vol. 264, no. 2, pp. 358-368, 1999.

[40] H. Rooki, K. Khajeh, A. Mostafaie, S. Kashanian, and S. Ghobadi, "Partially folded conformations of bovine liver glutamate dehydrogenase induced by mild acidic conditions," Journal of Biochemistry, vol. 142, no. 2, pp. 193-200, 2007.

[41] P. Gupta, R. H. Khan, and M. Saleemuddin, "Trifluoroethanolinduced "molten globule" state in stem bromelain," Archives of Biochemistry and Biophysics, vol. 413, no. 2, pp. 199-206, 2003.

[42] A. Naeem, K. A. Khan, and R. H. Khan, "Characterization of a partially folded intermediate of papain induced by fluorinated alcohols at low pH," Archives of Biochemistry and Biophysics, vol. 432, no. 1, pp. 79-87, 2004.

[43] P. R. Callis, "1 $\mathrm{L}_{a}$ and ${ }^{1} \mathrm{~L}_{b}$ transitions of tryptophan: applications of theory and experimental observations to fluorescence of proteins," Methods in Enzymology, vol. 278, pp. 113-150, 1997.

[44] C. Duy and J. Fitter, "How aggregation and conformational scrambling of unfolded states govern fluorescence emission spectra," Biophysical Journal, vol. 90, no. 10, pp. 3704-3711, 2006.

[45] M. Balsera, J. B. Arellano, F. Pazos, D. Devos, A. Valencia, and J. de las Rivas, "The single tryptophan of the PsbQ protein of photosystem II is at the end of a 4 - $\alpha$-helical bundle domain," European Journal of Biochemistry, vol. 270, no. 19, pp. 3916-3927, 2003.

[46] L. Stryer, "The interaction of a naphthalene dye with apomyoglobin and apohemoglobin. A fluorescent probe of non-polar binding sites," Journal of Molecular Biology, vol. 13, no. 2, pp. 482-495, 1965.

[47] M. Engelhard and P. A. Evans, "Kinetics of interaction of partially folded proteins with a hydrophobic dye: evidence that molten globule character is maximal in early folding intermediates," Protein Science, vol. 4, no. 8, pp. 1553-1562, 1995.

[48] Y. H. Wong and S. Tayyab, "Protein stabilizing potential of simulated honey sugar cocktail under various denaturation conditions," Process Biochemistry, vol. 47, no. 12, pp. 1933-1943, 2012.

[49] S. S. Leal and C. M. Gomes, "Studies of the molten globule state of ferredoxin: structural characterization and implications on protein folding and iron-sulfur center assembly," Proteins: Structure, Function, and Bioinformatics, vol. 68, no. 3, pp. 606-616, 2007.

[50] J. M. Mancheno, V. de los Rios, A. M. del Pozo, M. E. Lanio, M. Onaderra, and J. G. Gavilanes, "Partially folded states of the cytolytic protein sticholysin II," Biochimica et Biophysica ActaProtein Structure and Molecular Enzymology, vol. 1545, no. 1-2, pp. 122-131, 2001.
[51] A. R. Merrill, L. R. Palmer, and A. G. Szabo, "Acrylamide quenching of the intrinsic fluorescence of tryptophan residues genetically engineered into the soluble colicin El channel peptide. Structural characterization of the insertion-competent state," Biochemistry, vol. 32, no. 27, pp. 6974-6981, 1993.

[52] P. D. W. Eckford and F. J. Sharom, "Functional characterization of Escherichia coli MsbA: interaction with nucleotides and substrates," Journal of Biological Chemistry, vol. 283, no. 19, pp. 12840-12850, 2008.

[53] B. F. Peterman and K. J. Laidler, "Study of reactivity of tryptophan residues in serum albumins and lysozyme by N-bromosuccinamide fluorescence quenching," Archives of Biochemistry and Biophysics, vol. 199, no. 1, pp. 158-164, 1980.

[54] J. K. Yadav and V. Prakash, "Stabilization of $\alpha$-amylase, the key enzyme in carbohydrates properties alterations, at low $\mathrm{pH}$," International Journal of Food Properties, vol. 14, no. 6, pp. 11821196, 2011.

[55] S. Lee, H. Oneda, M. Minoda, A. Tanaka, and K. Inouye, "Comparison of starch hydrolysis activity and thermal stability of two Bacillus licheniformis $\alpha$-amylases and insights into engineering $\alpha$-amylase variants active under acidic conditions," Journal of Biochemistry, vol. 139, no. 6, pp. 997-1005, 2006.

[56] K. Khajeh, B. Ranjbar, H. Naderi-Manesh, A. E. Habibi, and M. Nemat-Gorgani, "Chemical modification of bacterial $\alpha$-amylases: changes in tertiary structures and the effect of additional calcium," Biochimica et Biophysica Acta-Protein Structure and Molecular Enzymology, vol. 1548, no. 2, pp. 229-237, 2001.

[57] M. S. Zaroog and S. Tayyab, "Formation of molten globule-like state during acid denaturation of Aspergillus niger glucoamylase," Process Biochemistry, vol. 47, no. 5, pp. 775-784, 2012.

[58] G. R. Kumar, A. Sharma, M. Kumari, M. V. Jagannadham, and M. Debnath, "Equilibrium unfolding of $A$. niger RNase: $\mathrm{pH}$ dependence of chemical and thermal denaturation," European Biophysics Journal, vol. 40, no. 8, pp. 923-935, 2011.

[59] C. H. I. Ramos and R. L. Baldwin, "Sulfate anion stabilization of native ribonuclease A both by anion binding and by the Hofmeister effect," Protein Science, vol. 11, no. 7, pp. 1771-1778, 2002. 

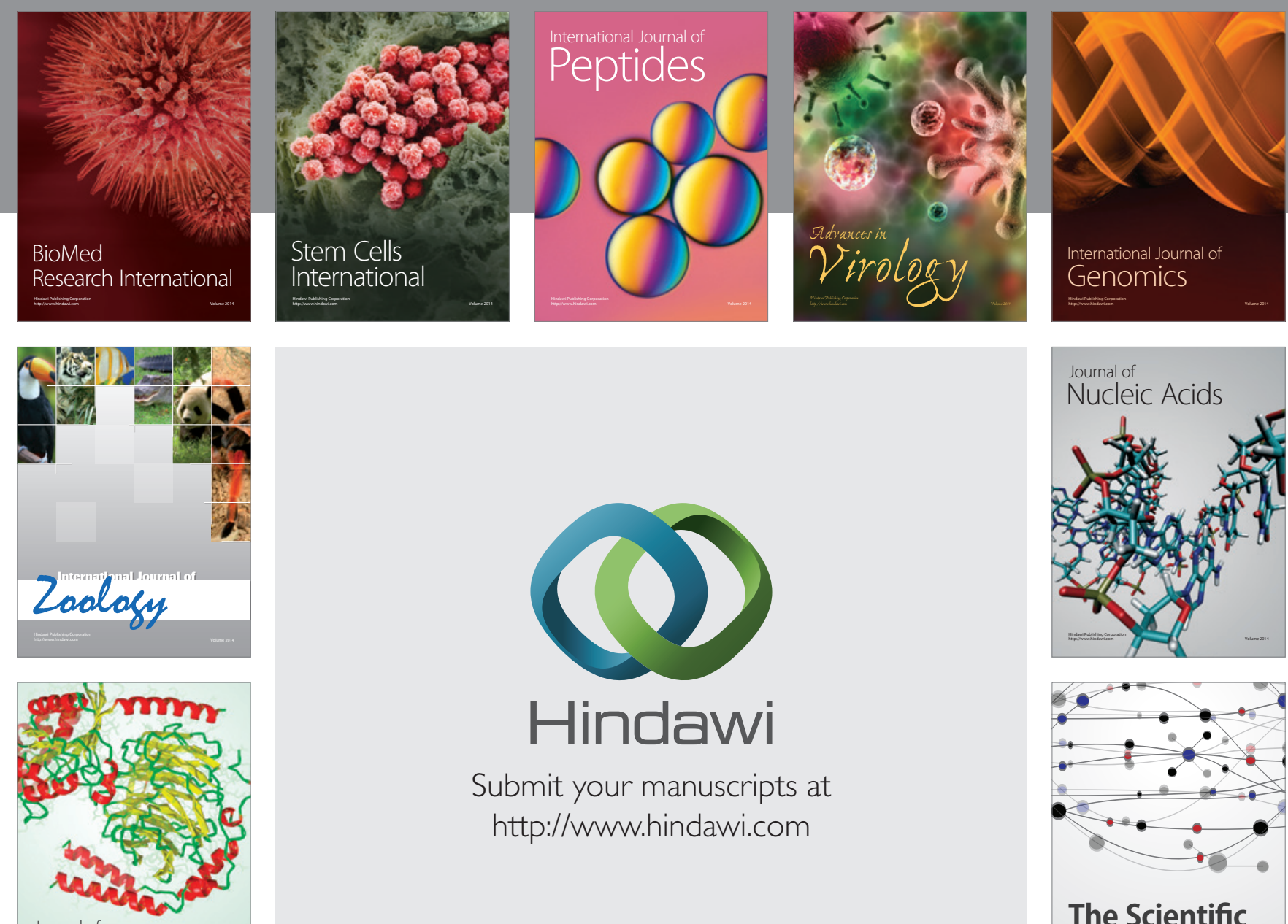

Submit your manuscripts at

http://www.hindawi.com

Journal of
Signal Transduction
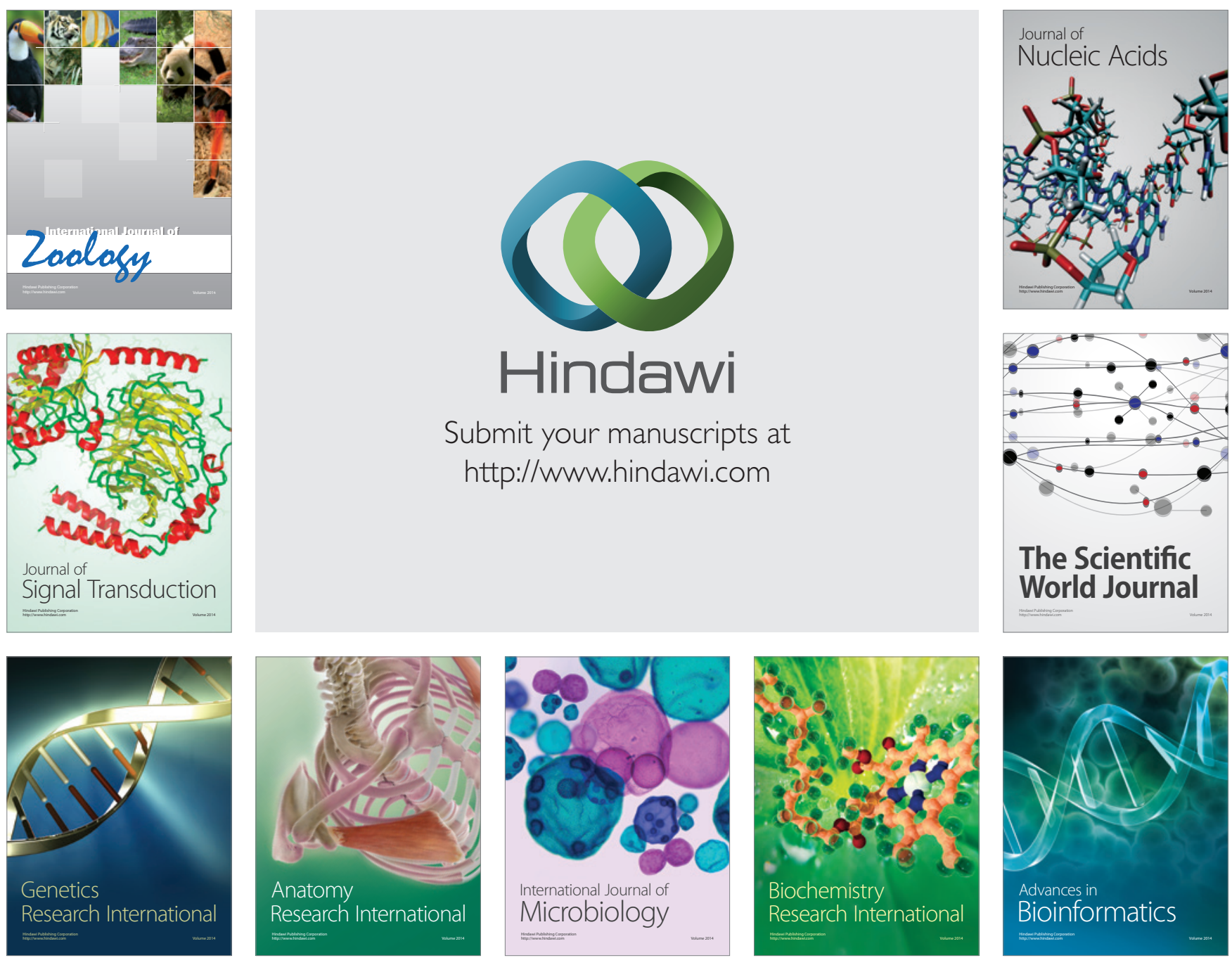

The Scientific World Journal
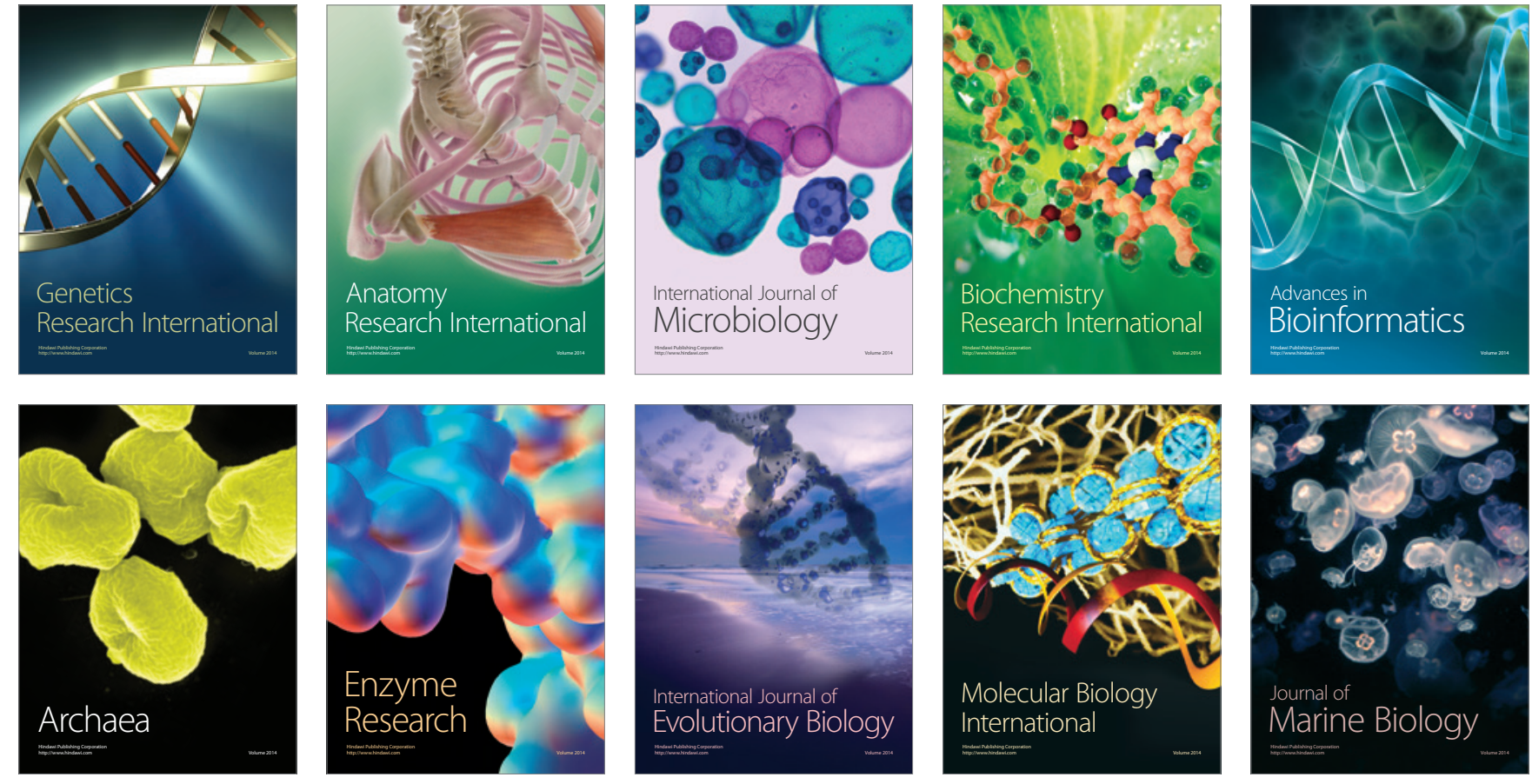